\title{
Article
}

\section{Security and democratic equality}

\author{
Brian Milstein
}

Goethe University Frankfurt, 60323 Frankfurt am Main, Germany.

brian.m.milstein@gmail.com

\begin{abstract}
After a recent spate of terrorist attacks in European and American cities, liberal democracies are reintroducing emergency securitarian measures (ESMs) that curtail rights and/or expand police powers. Political theorists who study ESMs are familiar with how such measures become instruments of discrimination and abuse, but the fundamental conflict ESMs pose for not just civil liberty but also democratic equality still remains insufficiently explored. Such phenomena are usually explained as a function of public panic or fear-mongering in times of crisis, but I show that the tension between security and equality is in fact much deeper and more general. It follows a different logic than the more familiar tension between security and liberty, and it concerns not just the rule of law in protecting liberty but also the role of law in integrating new or previously subjected groups into a democratic community. As liberal-democratic societies become increasingly diverse and multicultural in the present era of mass immigration and global interconnectedness, this tension between security and equality is likely to become more pronounced.
\end{abstract}

Contemporary Political Theory (2021) 20, 836-857. https://doi.org/10.1057/s41296020-00446-w; advance online publication 13 October 2020

Keywords: security; equality; democracy; rights; liberty; emergency powers

After a spate of terrorist attacks in European and American cities, the politics of counterterrorism are again high on the agendas of liberal democracies, with several reintroducing a variety of emergency securitarian measures, or ESMs. Over the last few years, multiple Western governments, including France, the UK, Belgium, Bulgaria, Luxembourg, the Netherlands, Hungary, Poland, and Slovakia, have sought to expand police powers of surveillance and detention, reactivate emergency laws that have fallen latent but remain on the books, or ease procedures for declaring states of emergency as a matter of counterterrorism policy (Amnesty International, 2016, 2017; Human Rights Watch, 2016).

Examinations of the challenges ESMs pose for liberal democracy are typically framed in terms of the so-called 'trade-off' between security and liberty and, more generally, between emergency prerogative and the rule of law (Waldron, 2003; 
Gross, 2003; Gross and Ní Aoláin, 2006; Ackerman, 2006; Scheuerman, 2006; Lazar, 2009; Posner and Vermeule, 2011; Ramraj, 2012; Sorell, 2013). This was a prominent feature of the debate in the years following the 9/11 attacks, as scholars and policymakers argued over whether it could ever be consistent with the principles of liberal democracy to violate, curtail, or weaken civil liberties in the name of protecting citizens from threats such as terrorism. More recently, states have increasingly found themselves responding to acts by 'homegrown' terrorists, adding further questions about democratic multiculturalism and the nature of citizenship in an age of accelerating migration and global interconnectedness. While the old security/liberty tension has by no means lost its relevance, it does not by itself encompass the full span and weight of the challenges we face today. Increasingly important is a second tension, the tension between security and equality, which puts front and center the risks ESMs pose to the idea of a diverse democratic community of not just free but equal citizens.

The propensity of ESMs to compromise equality is well known, both among scholars and beyond the academy. One need to only think of the internment of Japanese-Americans during World War II, the routine harassment of Irish citizens of the UK under the Prevention of Terrorism Acts, and the widespread discrimination against Muslims (and persons 'mistaken' for Muslim) since 9/11, to name some notorious examples. Jeremy Waldron, Oren Gross, and many others have noted how the trade-off between security and liberty often turns out in practice to mean trading the liberty of some for the security of others (Waldron, 2003, pp. 200-204; Gross, 2003, pp. 1083-1089; Gross and Ní Aoláin, 2006, pp. 220-227). And yet it remains standard for leaders to justify the need for ESMs on the grounds that the sacrifices they involve are demanded equally of everyone in the name of security provided equally to everyone.

Clear as it is that ESMs tend to have inegalitarian consequences, the full scope and depth of the tension between security and equality still remains insufficiently explored. The purpose of this article is to show, first, that ESMs are not just collaterally but intrinsically and indeed structurally inegalitarian, in ways that undermine not just liberal but also democratic ideals, by undermining the very conditions that make democratic equality among citizens possible. Moreover, it will show how the security/equality tension follows a different logic and poses different challenges than the more familiar security/liberty tension, and these challenges are bound to intensify as democracies become more and more pluralistic. This has important implications for how we understand the real consequences of ESMs. And because the security/equality tension runs deeper than can be adequately captured by the security/liberty framework, its implications for the cohesion of democratic communities are more extensive than can be accounted for in prevailing explanations. While the inegalitarian effects of ESMs are commonly attributed to the panicked overreactions of democratic citizenries or deliberate fear-mongering on the part of elites, as I will show using the case of the 
African-American community following 9/11, one need not be the target of some form of scapegoating to have one's equal standing as a citizen compromised. ESMs undermine equality in a very general way: they deprive laws of their capacities to establish equality and citizens of their capacities to claim it.

In what follows, I define ESMs as measures adopted in reaction to perceived security threats such as terrorism, which (a) curtail certain legally codified basic rights, such as rights to free movement or assembly, privacy rights, rights against unjustified search, seizure, or detention, or rights to legal counsel or fair judicial proceeding, and/or (b) expand discretionary police powers to maintain order and security in ways that reduce the protective capacities or 'worth' of such legally codified basic rights, even if those rights are not formally rescinded. For present purposes, I do not take ESMs to include certain broader and overtly anti-democratic uses of emergency rule, such as censorship of the press and media, banning persons or parties from standing for office, the arrest of public officials, cancellation of elections, or extra-parliamentary alteration of the constitution. My focus here is on a specific use of emergency powers - as measures put into place in a heretoforerobust liberal democracy in response to increased general threats to security and public safety. ${ }^{1}$

For the sake of argument, I will also assume that it is possible to distinguish what is and is not a true emergency, and that whatever ESMs are implemented in times of emergency can be implemented on a temporary basis. Those familiar with the literature on emergency powers know that periods of norm and exception have a way of blurring into one another. In fact, it is quite questionable how often expansions of government and police power, enacted on the pretext of being temporary, ever truly remain so (Rossiter, 2002 [1948], pp. 295-296; Scheuerman, 2006; Gross and Ní Aoláin, 2006, pp. 171-243). After all, important features of the USA PATRIOT Act and the 2015-2017 French state of emergency remain in effect today. This is surely already problematic for democratic equality. In addition, some theorists have posited extended conceptions of exceptionality that can be used to interpret modern governmentality generally, where talk of security and order legitimizes a police decisionism that permeates everyday life (Agamben, 2005; Hussain, 2007; Mehozay, 2016). However, for present purposes, I want to bracket these views. I argue that even a generous characterization of emergency authority one that can distinguish norm and exception - is still bound to run into tension with democratic equality.

\section{Security Versus Equality}

Democratic equality is the form of equality constitutive of democratic citizenship, functioning at once as a social and political ideal, a procedural ground, and a standard of inclusion. It is a social and political ideal that stands opposed 'to 
oppression, to heritable hierarchies of social status, to ideas of caste, to class privilege and the rigid stratification of classes, and to the undemocratic distribution of power' (Scheffler, 2003, p. 22; see also Anderson, 1999; Armstrong, 2006). Pitting itself in opposition to hierarchy and stratification, democratic equality is often identified with principles of 'non-domination' or 'non-subjection' (Garrau and Laborde, 2015; Viehoff, 2014). It is also the procedural ground upon which decisions, policies, and laws made can be understood as democratic, such that each citizen subject to the law can at the same time understand oneself as an equal coparticipant in the authorship of the law. Hence, Daniel Viehoff describes the authority of democracy as stemming from its ability to achieve 'coordination without subjection' (Viehoff, 2014). But democratic equality also provides the standard according to which citizens understand themselves as members of a democratic community. Accordingly, equality of status is the key standard of inclusion by which citizens come together to constitute a demos, a democratic 'we.' Particularly in diverse and multicultural societies, equal citizenship demands every person be able to see themself as a fully included co-participant in a common democratic enterprise, unburdened by any status or power differential conferred by virtue of one's race, ethnicity, or cultural affinity, such that every citizen has equal power to set the terms of one's relationships with other citizens and society at large (Hayward, 2011). To be a citizen among others is to be an equal; to be denied one's status as an equal is to be denied one's full standing as a citizen among others.

As already noted, debates about ESMs are typically presumed to concern a tradeoff between security and liberty. As Jeremy Waldron observes, it is at least possible to think about this trade-off in a way that appears consistent with liberal-democratic ideals: there does not appear to be any reason in principle why citizenry cannot democratically choose more liberty in exchange for less security and vice versa. Waldron does not think such a trade-off is a good idea, but it nevertheless seems plausible for a community of citizens to negotiate, adjust, and settle on an acceptable balance (Waldron, 2003, pp. 192-194). And yet what makes it seem plausible is precisely that such a trade-off would apply to everyone equally: it is 'we' who decide what kind of trade-off is appropriate, it is 'we' who share in its benefits and burdens, and it is 'we' who decide when that trade-off should be revisited. The trade-off between security and liberty rests on the assumption of a prior equality among those making the trade-off; it also rests on the assumption that that equality will not be affected by it.

Indeed, what happens if the equality that is the premise behind the security/ liberty trade-off is itself made subject to a trade-off? This poses a very different kind of problem. More fundamental than the obvious questions it raises (Whose equality? And for whose security?) is how relations of equality establish the demos as a collective 'we' capable of making democratically legitimate decisions (Viehoff, 2014). If the 'we' that makes the trade-off is defined by the fact that it comprises a citizenry of equals, then, should that equality be altered, the 
constitution of that 'we' changes: the collective who opts for the trade-off no longer mirrors those who will be affected by it in the same way, and the democratic character of the community is eo ipso undermined.

Could it be nevertheless possible to justify a trade-off between security and equality in a way consistent with liberal-democratic ideals? Perhaps one could make a utilitarian argument that it is acceptable to trade equality for security so long as it creates the most benefit for the greatest number of persons. In theory, a community of free and equal citizens may agree that, to protect society as a whole, it may be necessary and rational to accept ESMs that come down harder on some than others. But this rationalization only makes democratic sense if it were not known ahead of time who would be the winners and losers of this agreement - that is, if the risks of finding oneself subject to inegalitarian effects were themselves distributed equally. Yet these risks may not be distributed equally; indeed, who would suffer more than others under emergency authority is often quite predictable. In this scenario, a community would have to agree to sacrifice the equal rights of certain minorities for the security of the whole. Only a brute majoritarianism could justify this course of action and have any claim to calling itself democratic, but few today would consider this consistent with liberal democracy.

For such a policy to be accepted by the entire citizenry, those minorities who knew they were likely to be disproportionally affected by emergency measures would effectively have to accept and ratify their own inequality. But what if those minorities refuse? Would they not be accused of being unpatriotic or not caring sufficiently for the good of the community? Even if they could answer such charges, the very notion of being expected to 'prove their worthiness' as citizens in a way not expected of others is already problematic from an equality perspective. In any event, minorities at greater risk would have to agree that, in times of emergency, they are in effect no longer to be considered equal members of the community to be protected, which means that some groups would be full members of the democratic community all of the time and others only some of the time. But this would amount to accepting a lower class of citizenship altogether: a part-time equal is not an equal. And even were a minority to accept this trade-off initially, their loss of democratic equality means that, should reasons arise to revisit the trade-off, they would no longer be equal participants in the renegotiation. In other words, the notion of a trade-off between security and equality is contradictory from the purview of liberal democracy, for it requires either subjugating questions of liberty and equality to brute majoritarianism, bullying minorities into accepting periodic domination, or designating some members as not being full equals to begin with. 


\section{The Limits of the 'Scapegoat' Explanation}

There are clear normative problems with the idea of an express trade-off between security and equality. Despite this, ESMs have a long history of purchasing security for some with the rights of others, turning segments of a population into 'suspect communities' who do not enjoy equal status as full citizens (Hillyard, 1993; Moeckli, 2008; Pantazis and Pemberton, 2009; Awan, 2012). As noted in the introduction, those who write on emergency powers are well aware of this. But despite the ubiquity of this phenomenon, they tend to diagnose the problem as a side-effect of ESMs instead of as a structural problem inherent to the logic of ESMs as such. ESMs are primarily assumed to affect liberty, not equality.

Consider, for example, what we might call the standard justification for ESMs the rather consistent repertoire of reasons given for needing to derogate from normal laws and procedures in the name of security, necessity, urgency, exceptional times, public safety, or self-preservation. ESMs tend to be justified on Hobbesian grounds, on the notion that the first question of political society is the question of securing order, 'because solving it is the condition of solving, indeed posing, any others' (Williams, 2005, p. 3; see also Lazar, 2009, p. 95; Sorell, 2013). The reasoning is that without state control, law, and order, there can be no liberty or democracy, and political society will collapse into chaos. It is therefore necessary, in times of extreme crisis, for citizens to cede their rights back to the state, or in Clinton Rossiter's words, 'to renounce their freedom for a little while in order to preserve it forever' (Rossiter, 2002 [1948], pp. 13-14).

This standard justification can also be framed in 'Schmittian' terms, according to which legal mechanisms are too slow or otherwise inadequate to the demands of preserving society in times of emergency (Scheuerman, 2006). But while Schmitt was interested mainly in the presuppositions of legal rationality and decision, Hobbes incorporates this standard justification into the very fabric of the social contract, addressing himself directly to the needs of social integration and the putative interests of citizens. Not only does Hobbes stress the priority of security over liberty and democracy, he even gives a quasi-democratic and egalitarian justification for it. Because political society will crumble without security, every person has an equally weighty interest in it; in times of emergency, enhanced state power protects everyone equally because the risks endanger everyone equally. This makes security a collective good that is of equal benefit to every citizen, thus every citizen shares an equal interest in prioritizing it over other rights and privileges.

This reasoning taps into presuppositions about the nature of political society that lie deep in the social contract tradition, where rights can be understood to merely 'secure' an already existing (or at least presumptive) equality among persons who are free and equal by nature. So long as we follow this line of reasoning, there is no 
reason to think that ESMs will necessarily affect the equal standing of citizens in society.

Why, then, do ESMs so often generate inegalitarian effects? The most widely offered explanation is what we might call the popular scapegoating thesis: panicked majorities fixate on some minority group on which to project some kind of generalized responsibility for the emergency. Bruce Ackerman writes of the 'wartime hatreds' and 'prevailing demonology' that accompanies each national security threat (Ackerman, 2006, pp. 61-63, 81-82). A variation of this results from fear-mongering, when elites seek to shore up their own power or otherwise exploit a crisis by deliberately stoking such forms of panic and projection. This does seem to fit many cases; nevertheless, we should be cautious about framing the matter in this way. While such forms of scapegoating are factors, assigning too much weight to populist overreaction or demagoguery risks framing the issue as one of liberalism versus democracy in an undesirable way. In the extreme, it lends itself to the dangerous conclusion that democratic majorities are too mercurial and democratic procedures too unreliable in times of emergency, urging greater deference to the extra-democratic aspects of emergency power. But if (as I will argue shortly) ESMs are structurally predisposed to inegalitarian effects, then such a conclusion would recommend derogation of democracy at precisely the moment when democracy is most vulnerable and in need of protection.

A somewhat different argument is that ESMs bring inegalitarian burdens because majorities and elites already know - or at least believe - that it is not they who will be bearing the brunt of them (Gross, 2003, pp. 1082-1089; Gross and Ní Aoláin, 2006, pp. 220-227; Moeckli, 2008). We can call this the privileged indifference thesis. Waldron describes this dynamic in terms of a cost-benefit trade-off between the interests of the innocent and the welfare of the community, noting how the apparent reasonableness of such a trade-off is largely dependent on the knowledge that one is unlikely to be one of those affected innocents and, moreover, that assessment of likelihood is largely a function of one's membership in a privileged ethnic or religious group (Waldron, 2003, pp. 200-204). Similarly, Gross and Fionnuala Ní Aoláin describe a 'degree of separation' whereby some are more likely to accept restrictions on liberty because they assume only others will be affected (Gross, 2003, pp. 1082-1089; Gross and Ní Aoláin, 2006, pp. 72-79, 94-98). But this line of reasoning does not so much explain the tension between security and equality as give an account of why some might find the resulting inegalitarian effects acceptable, whatever the explanation for them might be.

Protecting against such phenomena as popular scapegoating and fear-mongering is usually framed in terms of defending the rule of law in times of crisis - that is, with preserving civil liberties, separation of powers, and constitutional governance against arbitrary power. And many scholars, including Ackerman, Waldron, and Gross, do argue that this requires a robust defense of democratic institutions, partly because of fear of accreting too much power to the executive, but also because it is 
widely agreed that the judiciary's record as a check on abuses of emergency powers has been historically spotty at best, with a tendency at times even to 'show itself more executive minded than the executive' (Atkin, 1941; see Waldron, 2003, p. 191; Gross and Ní Aoláin, 2006, pp. 72-79, 94-98; Ackerman, 2006, pp. 22-35, 60-66). Nevertheless, framing the security/equality tension as a collateral sideeffect of ESMs presents problems that run counter to these stated goals. For starters, it allows the security/equality tension to be posed as a conflict between rule of law and democracy. This only gives ammunition to critics who would insist on the fickleness of democracy under crisis: it allows democracy to be presented as something we need protection from rather than something we need to protect (Schmitt, 1985 [1922, 1934]; Posner and Vermeule, 2011). In any event, the problem of preserving not just liberty but equality in times of crisis touches upon another dimension that is only partially captured by this framing. To fully grasp the tension between ESMs and democratic equality, we need to consider not just the rule of law in preserving civil liberties and democratic institutions but also the role of law in holding together and maintaining a liberal-democratic society of citizens able to recognize one another as equals.

\section{The Role (Not Just Rule) of Law}

In arguing that the security/equality tension is distinct from the more familiar security/liberty tension, I am not arguing we have to choose between thinking in terms of one or the other. And to say that the question of preserving rule of law captures only part of what is at issue is not to say it is immaterial. Rather, in arguing we need to consider not only the rule but also the role of law, I am merely arguing for the addition of another layer of perspective on how we understand the effects of ESMs.

For example, post-9/11 debates over security, liberty, and the rule of law were often framed around matters such as warrantless search or detention or hypotheticals such as the famous 'ticking time-bomb' scenario (see Gross, 2003, pp. 1097-1001; Ackerman, 2006, pp. 22-38, 105-114). These followed the format of a certain utilitarian calculus whereby the issue at hand is whether it is permissible for state officials to exercise discretionary violations of this or that person's civil liberties. Whatever else may be said about these sorts of dilemmas, what is notable is how they are framed in such a way that takes their hypothetical subjects of detention or interrogation as individuals. What is being weighed are the rights of single persons against the needs of the community at large. What is left obscure, however, is how that same individual may be understood as a member of that same community: how individuals stand in relation to each other as citizens, and how these relationships taken together are constitutive of the community whose needs are ostensibly being protected. 
Equality is by definition a relational concept. If the relation of a subject to the rest of the community cannot be thematized, then neither can that subject's status as an equal member of that community. This is why capturing how ESMs affect equality requires an additional layer of perspective.

In important ways, equality, like liberty, is institutionalized in liberal-democratic societies through legal means. Law, in the form of a complex of liberal and political rights, serves crucial purposes of encoding basic freedoms in liberal-democratic societies. But law does not merely function to protect individuals qua individuals: it is also a medium for the social integration and democratic cohesion of a political society with diverse membership.

We can see this initially in the way the same schedules of rights that legally preserve individual liberty against arbitrary violation by the state also help to institutionalize relations of democratic equality. Political theory conventionally distinguishes between liberal rights (also known as civil liberties, private autonomy, or human rights) and political rights (also known as participatory rights or public autonomy), wherein the former include basic rights to privacy, property, protection from state intrusion, and fair judicial proceeding, while the latter include rights to vote and stand for public office. There are also basic rights that straddle both categories, such as rights to freedom of expression, conscience, movement, and assembly. Yet, democratic equality requires both sets of rights. Jürgen Habermas has been the most explicit in arguing that liberal and political rights, or private and public autonomy, are 'co-original' (Habermas, 1996, pp. 82-131). ${ }^{2}$ Only with full security in one's person and equal protection under the rule of law can citizens make full use of their normative powers as equal participants in a democratic community; conversely, only as full and equal participants in a democratic community can each citizen guarantee for oneself the liberty sufficient to be fully secure in one's person. A derogation of either side of this equation would threaten to break the virtuous circle that keeps liberty and democracy in mutual support of one another and, accordingly, threaten the status of citizens as democratic equals.

This is why, for example, Annabelle Lever (2006) insists that freedom of expression and association cannot be qualified by distinctions between what counts as 'properly political' versus 'merely personal' forms of speech and association. Even rights that do not appear at first glance political are essential to citizens' capacities to feel secure in their ability to formulate political opinions and choices of their own and to decide how to act on them, and this makes them essential to their abilities to freely associate, organize, and protest. Rights such as the right to privacy are essential to make citizens capable of 'exploring competing conceptions of politics, different ways of associating together, and different reasons for doing so' (Lever, 2006, p. 150). More fundamentally, privacy rights protect what Jean Cohen calls 'the right to be different' (Cohen, 1996, pp. 201-202). They allow individuals in a democratic society to develop their own identities, personalities, 
and beliefs without fear of the state or the majority culture, and it is only on these terms that they can understand themselves as equal members deserving of equal respect and standing. The same can be said about equal protection before the law and rights associated with criminal procedure (Sklansky, 2005). Bennett Capers observes how racial profiling and other unequal criminal justice practices deny victims the sense of being equal co-owners of the society of which they are members: they 'send the expressive message, from a representative of the state, about the continued existence of a racial hierarchy in which some citizens enjoy more privileges and immunities, more freedom of movement, and a greater sense of belonging, than others' (Capers, 2011, p. 28). Equal rights before the law anchor the capacities of citizens to recognize each other, understand themselves, and act in a democracy as equals.

Legally codified rights thus play a dual role in regulating not only the relation of each individual citizen to the state but also the status relations of citizens relative to each other. From the perspective of democratic equality, these two roles are interconnected: equal status among citizens begins with equality of rights before the state. And yet it is important to note an ambiguity here in the meaning of 'equal.' When we speak of 'equal rights' or even 'equality before the law,' by 'equal' we typically invoke a distributive criterion: the rights are granted to each member of society in equal amounts. In contrast, the sense of 'equal' in 'equal status' is relational: it refers to the relative position of citizens to each other. The equal distribution of rights is the means, but their relevance to democratic citizenship depends on having equal relations of status as their end (cf. Rawls, 2005, pp. 325-327). Accordingly, necessary as the former may be to achieving the latter, it is not in and of itself sufficient. Also relevant is what we might call the quality of the rights themselves: their strength, their scope, the adequacy of their formulation, and the way they combine with other rights. An equal right to legal representation may mean little for equality if making effective use of that right remains hindered by other inequalities left unaccounted for (cf. Chin, 2013). An equal right to attend college may be ineffective so long as secondary schools remain segregated and underfunded in minority neighborhoods. Whether and how the distribution and quality of equal rights contribute to equality of status is thus a more complex question than it first appears. Often, it is a question that can only be evaluated in reference to a particular historical or political situation, i.e., who are the people among whom relations of equality are to be established through rights, and what the relations between them would be like otherwise (see Gotanda, 1991; MacKinnon, 2011; Crenshaw, 2019).

This last point allows us to distinguish between two distinct but interrelated ways of thinking about the function of legally codified rights. The formal level refers to the way in which the distribution and quality of rights are codified into general legal principles that hold for all citizens. But behind this formal way of thinking about them is a second, sociopolitical level, where rights must be understood in 
terms of what is needed to establish relations of equality among rights-bearers who would otherwise not be recognized as equals. A focus on the rule of law that does not also consider the role of law risks looking only at the first level without also considering what it owes to the second. For it is at this second level that ESMs that roll back rights or expand police power in ways that reduce the efficacy of rights can have a deleterious effect on democratic equality.

Recall the standard justification for ESMs, the argument that security is a collective good of equal benefit to every citizen, and therefore, in times of emergency, every citizen has an equal interest in prioritizing security over certain basic rights. Underlying this justification is an assumption that rights merely 'secure' a preexisting equality, i.e., that an equal distribution of rights is sufficient to convert the natural moral equality people possess into equality among citizens. Hence, so long as ESMs apply equally to everyone, suspensions of rights or expansions of state power should not of necessity affect equality. But this assumption conflates the two relationships noted above between the notion of equality and that of rights. It assumes equality can be preserved among citizens so long as the equal distribution of rights remains the same, even if the quality is altered; it overlooks the ways in which the latter is as crucial as the former.

In actually existing liberal democracies, rights function not just to secure equality among presumptive equals in a state of nature, but also to establish equality among classes and groups of persons of historically unequal status, that is, as not just formally codified principles but political achievements grounded in past and present struggles for equal status in political society (see, for example, Bobbio, 1990, pp. 6-8; Marshall and Bottomore, 1992; Habermas, 1996, pp. 76-78; Ingram, 2013, pp. 243-245). This is reflected in the historical progression of the establishment of rights, which first existed mainly for white, propertied men of the majority confession and was only gradually expanded to encompass the unpropertied, religious minorities, women, and non-whites, as well as new immigrant cohorts. The idea of equal rights does not merely affirm, at the formal level, the liberal notion that all are created equal; it also presupposes the recognition, at the sociopolitical level, that all would not be treated as equals without them, by the state or by fellow citizens.

This history of the demos of equal rights-bearers and citizens tells a different story than the contractarian story that underwrites the standard justification for ESMs. In fact, from a sociopolitical standpoint, the achievement of formal basic rights is often sufficient only to grant historically subordinated actors a legally guaranteed starting point within protracted struggles for equal inclusion. These include struggles to redeem the equal distribution of rights in substantive everyday terms such as equal access to educational opportunities, employment, interpersonal trust, and viability for public office. Yet, these struggles can also be to adjust the quality or 'worth' of rights in ways that better address persistent sociopolitical inequalities (Rawls, 2005, pp. 325-327). This can be done via legal correctives 
aimed explicitly at countering prejudice and inequality, such as antidiscrimination law, pro-diversity initiatives, redistributive policies, or provision of public services.

But there are other ways of adjusting the quality of rights that do not target status inequalities explicitly but rather correct for them by reinterpreting and ratcheting up standards for already existing rights. Notably, these often include rights regarding criminal detention and judicial procedure, the rights most commonly affected by ESMs. In the United States, for example, many of the twentieth-century Supreme Court decisions on criminal procedure were fought by appellants of low socioeconomic or minority background - particularly African-American background. Michael Klarman traces this process as far back as the 1920s, as an effort by the federal judiciary to reassert the supremacy of fair judicial proceedings against widespread lynchings of Black suspects in the American south (Klarman, 2000). The primary wave, however, came in the 1960s with landmark cases such as Mapp, Gideon, Escobedo, and Miranda. In William Stuntz's words, 'Warren-era constitutional criminal procedure began as a kind of antidiscrimination law' (Stuntz, 1997, p. 5). While the major decisions on police searches and seizures, rights to counsel during interrogations, and protections against self-incrimination nominally had to do with the clarification of rights that long applied to all citizens, they were made on the basis of the realization that existing interpretations still left minority and lower-class suspects exposed to unacceptable levels of subjugation and abuse (Capers, 2011; Neuborne, 2011; Chin, 2013).

At the formal level, these rights enhancements sediment neutrally into the way we interpret general principles of liberal and political rights enjoyed in common by free and equal citizens. But at the sociopolitical level, these same rights track the persistence of the very inequalities law aims to dissolve at the level of formal legal principle. They testify to the role of law in liberal-democratic society to not only secure equality but actively pursue its establishment. Conversely, they testify to the inequalities that may yet reemerge from beneath the surface were such law to be somehow rolled back.

What we have been calling the standard justification for ESMs obscures the difference between these two perspectives. It assumes the equal standing of citizens is secured on the basis of formal equality of rights, while overlooking the role of law in establishing equal standing through adjustments to the quality and worth of rights. It thus invites the misleading calculus that, because every citizen has an equal stake in the security of the free state, every citizen is making an equal sacrifice under ESMs. But even if we can speak of a formal equality of rights, we can still distinguish at the sociopolitical level between those fully secure in their rights, immunities, and privileges and those who, due to their history of marginalization, find their hold on equality rather tenuous. In other words, there is nothing about formal equality of rights that is inconsistent with a sociopolitical reality in which some are more reliant on those rights than others for their status as equals. Such considerations about the role of law reflect the sense in which 
democratic equality remains an ongoing project. Whether we are speaking of historically subjected persons in society or newly arrived members in the process of integration, liberal-democratic societies are bound to encounter remaining inequalities of status under law that have yet to be remedied. But a consequence of such remaining inequalities of status is that some effectively end up sacrificing more of their rights for the same security than their counterparts under emergency powers, while also taking on the added in security that comes with increased exposure to arbitrary state power and loss of status.

Whereas the standard justification assumes all are making sacrifices as equals, some are sacrificing the rights necessary to make them equals in the first place. Under ESMs, which involve either scaling back rights or expanding police power in ways that reduce the efficacy of rights, members of marginalized or previously unequal groups find themselves more exposed to possible discrimination and abuses of state power than others. This constitutes neither a necessary nor a sufficient condition that they will empirically face such discrimination and abuse, but it does create a substantial permissive condition by shearing away the legal resources necessary to combat it. Some neorepublican political theories classify this as already constituting a form of domination: even if not empirically subject to abuses, their freedoms and everyday lives become dependent on the arbitrary will of others (Pettit, 2012, pp. 60-64). Thus the curtailment of legal protections necessary for equality opens the way for majorities overtaken by panic or elites prone to fear-mongering to make scapegoats out of marginalized groups, place them under permanent state of suspicion, or otherwise arbitrarily subject them to intimidation, violence, and fear (Hillyard, 1993; Moeckli, 2008, pp. 193-222; Pantazis and Pemberton, 2009; Awan, 2012). Yet, as I will show, neither scapegoating nor fear-mongering is necessary for ESMs to prove deleterious to democratic equality.

\section{From 9/11 to Ferguson: Police Militarization and the War on Terror}

The standard justification, as we have seen, would expect derogations of rights and expansions of police power to be felt equally: equal sacrifice for equal security. On this view, there should be no reason to think there is anything about ESMs that must damage equality. Accordingly, when ESMs do seem to bring about inegalitarian effects, these are frequently attributed to collateral phenomena such as popular scapegoating or fear-mongering. But equality can suffer under ESMs even without these.

This can be seen in the case of police action against African Americans in the years following $9 / 11$. We already saw how many of the rights considered standard in U.S. criminal law and procedure arose out of struggles of African Americans against arbitrary police power and unequal interrogation practices. Similar 
struggles continue against widespread police brutality, racial profiling, and inequitable sentencing policies (Cole, 1999; Banks, 2003; Stuntz, 2008). One trend of note has been the growing prevalence and reliance on paramilitary police units (PPUs) in everyday policing, especially in poor and inner-city neighborhoods (Kraska and Kappeler, 1997, p. 12). Spurred by the decades-long War on Drugs, the number of local departments with PPUs had grown dramatically between the 1980s and 90s, and, in 1997, Congress authorized Program 1033, which authorized the Defense Department to transfer decommissioned military items to police departments (Kraska, 2007, p. 506; Hall and Coyne, 2013, p. 497).

This militarization of local policing accelerated dramatically during the War on Terror of the early 2000s (Kraska, 2007, pp. 511-512). After 9/11, the newly created Department of Homeland Security began to offer large funding grants to state and local law enforcement with the nominal aim of combating terrorism, while the wars in Afghanistan and Iraq produced a glut of military-grade weaponry, armored cars, personnel carriers, and other combat gear, which was passed on to local police via the 1033 Program (Hall and Coyne, 2013; Dansky et al, 2014). Very little of this money and equipment has been used for counterterrorism; however, it has greatly increased the prevalence of paramilitary tactics in everyday policing. And the brunt of this militarization has fallen disproportionately on minorities. According to the ACLU, ' 42 percent of people impacted by a SWAT deployment to execute a search warrant were Black and 12 percent were Latino' (Dansky et al, 2014, p. 36). This phenomenon achieved worldwide attention in Ferguson, Missouri, in 2014, when locals and activists protesting the shooting of Michael Brown were met by a police cavalcade of armored vehicles, riot gear, and assault rifles.

Here, post-9/11 policy changes had the effect of stripping away restraints against already existing sources of prejudice and institutionalized racism against certain minority communities. As noted, the rise of PPUs first can be traced to the 1980s and 90s, at the height of the War on Drugs, during which time African Americans and Latines found themselves targets of a large amount of fear-mongering by politicians and mass media about 'crack houses,' 'street gangs,' and 'superpredators' (Reeves and Campbell, 1994; Cole, 1999; Stuntz, 2008). It could even be claimed that, during this time, certain aspects of domestic policy had their own semblances to a 'state of emergency.' ${ }^{3}$ Yet, public support for a 'war' on drugs - an approach that understood the drug problem as a criminal policing issue as opposed to a treatment and prevention issue - was already waning by the turn of the century (Lock et al, 2002; Nielsen, 2010). But post-9/11 policy not only continued but accelerated the flooding local police departments with military equipment, which would be deployed against minorities in routine matters.

Indeed, by the turn of the century leaders of both major parties were making public statements about the injustices of police practices such as racial profiling. In summer 2001, the End Racial Profiling Act (ERPA) had wide bi-partisan support 
and was making its way through Congress. The bill promptly lost momentum after $9 / 11$, as leaders and security officials insisted that restrictions on profiling would hamper domestic efforts to combat terrorism. According to the NAACP, it would not be until the 2012 shooting of Trayvon Martin that racial profiling against African Americans would regain wide traction as a national issue (Kasravi, 2014, pp. 4-5, 18).

We thus see at least two effects of post-9/11 security policy that detrimentally affect democratic equality independently of popular scapegoating or fear-mongering. The example of increasing PPU usage provides a telling, though dynamic, example whereby sediments of previously existing forms of subjection are amplified through a new and ostensibly unconnected expansion of police powers. Here, ESMs exacerbate the already tenuous hold on equality of minority and disadvantaged groups and subjecting them to heightened levels of violence, intimidation, and arbitrary displays of coercion (Cole, 1999; Banks, 2003; Stuntz, 2008). In addition, the example of racial profiling indicates how the move toward ESMs can stall or roll back progress in ongoing struggles to achieve democratic equality in the first place. As we have seen, democratic equality is not something citizenries merely secure through law, but an ongoing project. In stifling such struggles in the name of security, the sacrifice of rights to security, though presented at the formal level as applying to all citizens equally, effectively denies struggling groups their claims to equality as citizens at the sociopolitical level.

\section{A Lockean Solution?}

A possible objection to the arguments above is that my account of the standard justification for ESMs, being grounded in 'Hobbesian' logic, does not take into account recent alternative, 'Lockean' readings of emergency authority. Derived from Locke's theory of prerogative, this approach interprets emergency authority not as the need to suspend laws but to act outside of or even against the law for the sake of its spirit. According to Locke, 'the people shall be judge' on whether an executive's actions were warranted or constitute an abuse of power (Locke, 1980 [1690], pp. 83-88 [\$§159-168]).

Oren Gross's Extra-Legal Measures model goes farthest in developing such a Lockean framework. Gross recognizes the tendencies of emergency powers to trample on civil liberties, the spotty record of the judiciary in checking executive power, and the tendency (mentioned briefly in the introduction) of emergency policies to become permanent features of state infrastructure. But he does accept enough of the Hobbesian standard justification to still insist officials require leeway in handling certain threats to security. His proposal is that, instead of formally suspending rights or instituting long-term emergency measures, officials should be allowed an informal margin of discretion to act extra-legally, that is, outside the 
limits of the law, even when it requires violating rights or acting beyond the enumerated powers of one's office (Gross, 2003; Gross and Ní Aoláin, 2006; cf. Tushnet, 2012). Gross believes such a model can succeed so long as two stipulations are met. First, the extra-legal prerogative depends on officials acting openly and transparently. Second, officials acting extra-legally must submit themselves to what he calls 'ex post ratification': procedures of public judgment that will ratify or condemn the extra-legal action with regard to its necessity and morality. In addition to preserving the integrity of the law, Gross's view is that the specter of public judgment will regulate the extra-legal prerogative by deterring officials from taking actions they cannot justify later.

Yet, the Extra-Legal Measures model does not resolve the tension between security and equality, and it may even exacerbate it. ${ }^{4}$ Ackerman and David Dyzenhaus worry that, by allowing agents to violate the law at their discretion and seek justification after the fact, the model essentially normalizes deviations from rights and legality in a way that makes rule of law generically unstable (Ackerman, 2006, pp. 88-89; Dyzenhaus, 2012). This is in itself problematic, for it risks putting the role of law in establishing and securing equality into a state of permanent tenuousness. But there is a deeper problem, in that the model of ex post ratification - of subjecting extra-legal actions to popular judgment after the fact - severs liberalism from democracy and effectively subjugates the former to the latter (cf. Chesterman, 2012). We saw above how liberal rights such as privacy and due process are as essential to democratic equality as political rights, as they provide the security in one's person necessary for citizens make full use of their normative powers as equal participants in a democratic community. It is the co-originality of these rights that secures the demos as a community of equals, which is a necessary condition for preventing a democracy from descending into brute majoritarianism. Yet, the ex post ratification model makes the equal rights of some contingent on the populist will of others, such that legitimizing extra-legal rights violations on this basis risks depriving victims of the security needed to participate on equal footing in the ratification process. It is not hard to imagine a local police chief taking the prerogative to subject a minority neighborhood to intrusive surveillance and searches, with an effect being that local residents become too fearful to organize as effectively as the chief's supporters not subject to the same intrusions. ${ }^{5}$

Ackerman recommends an alternative strategy whereby ESMs are codified but remain subject to legislative ratification at regular intervals of no more than a few months, with a supermajority threshold that increases at each interval (Ackerman, 2006, pp. 80-83). In principle, entrusting oversight of ESMs to legislative representatives may shield the democratic process from inequalities suffered by citizens under ESMs. Even still, this model suffers two weaknesses. First, it holds only in the short term. A democracy can only continue so long without the activity and input of the citizenry, and after a time - including but not only the next round of elections - it would be exposed to the same problems as the Extra-Legal 
Measures model. Second, the ability of a legislature to protect democratic equality over the course of an emergency - even with the proviso of escalating supermajorities - depends heavily on its ability to reflect the makeup of the citizenry in a way that eliminates unequal influences and guarantees the voice of peripheral minorities. It would certainly demand more stringent criteria of representative equality than any existing congress or parliament has come close to meeting.

And even if a system of representation could meet such stringent demands at one moment in time, it must face an additional difficulty in that citizenries today are increasingly unstable and shifting. Liberal-democratic societies are today massimmigration societies, with every new cohort presenting a new challenge for integration and a new reconfiguration of the demos. There will always be new groups of citizens struggling not to secure but for the first time to establish their equality as full citizens, and who will be the least secure in their political representation and the most vulnerable in their rights. Our current age of global interconnectedness and multiculturalism makes the role of law in achieving democratic equality more, not less essential in guaranteeing the equality of citizens, and yet it is precisely this role that emergency or extra-legal securitarian measures put in danger. So long as the achievement of democratic equality is an ongoing process, any scheme of democratic representation will fall short in its ability to compensate the loss of rights guarantees necessary for equal citizenship. If Carl Schmitt once argued that democracy is too slow for the needs of emergency governance, we might now ask if emergency governance is too slow for the needs of democracy.

\section{Conclusion}

More than just a central ideal, democratic equality is a necessary condition for members of liberal democracies to understand themselves as co-participants in a community of citizens. It is what enables citizens to join together in a democratic 'we,' and its maintenance is dependent on the establishment and preservation of the necessary distribution and quality of liberal and political rights. As we have seen, this has implications for debates over emergency powers usage that we do not find in the more familiar debate between security and liberty. For while a democratic 'we' can in principle negotiate and revise the way it conceives the proper balance between security and liberty, the same cannot be said of an analogous balance between security and equality, for any such trade-off by a democratic 'we' would involve bargaining away who can enjoy full status as a member of that 'we' in the first place.

We have also seen how the conflict between security and equality extends beyond empirical tendencies toward popular scapegoating, fear-mongering, or 
privileged indifference. Beyond interfering with the individual liberties of citizens, ESMs enacted in response to threats such as terrorism drain the rights of citizens of their capacity to maintain democratic equality in a very general way, such that their deleterious effects on equality can be felt even by minorities not publicly scapegoated for the emergency in question. Because citizens of diverse, multicultural, and differentiated societies have different relations to and different degrees of reliance on the complex of liberal and political rights necessary for democratic equality, ESMs that curtail these rights cannot avoid exposing more vulnerable groups and persons to domination and arbitrary abuses of power.

This conflict is easy to miss from the purview of our standard, social contract-based justifications of emergency powers, which suppose it to be in the equal interest of every citizen to temporarily cede one's rights back to the state for the sake of security. The social contract evokes an image of society as something self-contained and selfsufficient, with a pre-politically given and stable citizenry, whose equality does not need to be established by law but merely secured by it. Yet, as liberal-democratic societies become more multicultural and pluralistic, the shortcomings of this image and its assumptions become pressing. They are belied by the realities of the twentyfirst century, where liberal-democratic societies are mass-immigration societies, whose civic boundaries are not at all given, whose terms of inclusion must be continuously renegotiated, and whose ever-shifting membership requires the legal guarantees necessary for new groups to achieve the status of free and equal citizens.

In devising our models for preserving or reassuring a democratic citizenry in the face of emergency, we must keep in mind whose idea of a citizenry we are preserving or reassuring. For if the purpose of emergency measures is only to curtail liberal-democratic guarantees in order to preserve them thereafter, then preservation and reassurance are goods whose value must extend to the life of the community beyond the emergency itself. This recommends a wariness of measures that purport to save a community while shearing the bonds that hold it together.

\section{Acknowledgements}

Earlier versions of this paper were presented at the Philosophy and Social Sciences Conference in Prague and the Forschungskolleg Humanwissenschaften in Bad Homburg, Germany. I would like to thank Nate Adams, Idil Boran, Emilia Barreyro, Cristian Dimitriu, Rainer Forst, Petra Gümplová, Joshua Kleinfeld, Matthias Lutz-Bachmann, Alasia Nuti, Antoinette Scherz, Bill Scheuerman, Johannes Schulz, Ellinor Schweighöfer, Miriam Dajczgewand Świętek, Isaac Taylor, Luke Ulaş, Melissa Williams, Karen Zivi, and two anonymous reviewers for their helpful comments, discussion, and encouragement.

Funding Open Access funding enabled and organized by Projekt DEAL. 
Open Access This article is licensed under a Creative Commons Attribution 4.0 International License, which permits use, sharing, adaptation, distribution and reproduction in any medium or format, as long as you give appropriate credit to the original author(s) and the source, provide a link to the Creative Commons licence, and indicate if changes were made. The images or other third party material in this article are included in the article's Creative Commons licence, unless indicated otherwise in a credit line to the material. If material is not included in the article's Creative Commons licence and your intended use is not permitted by statutory regulation or exceeds the permitted use, you will need to obtain permission directly from the copyright holder. To view a copy of this licence, visit http:// creativecommons.org/licenses/by/4.0/.

\begin{abstract}
About the Author
Brian Milstein is a research associate in international political theory at Goethe University Frankfurt's Research Centre "Normative Orders" and Department of Political Science. He is the author of Commercium: Critical Theory from a Cosmopolitan Point of View (Rowman \& Littlefield International, 2015). His current research focuses on crisis theory and the concept of crisis in social and political thought.
\end{abstract}

\title{
Notes
}

1 The argument to follow proceeds with two caveats. First, a more general discussion of emergency powers might also acknowledge times when states have invoked such authority to uphold rights or equality when those entrusted with doing so prove unable or unwilling (see, e.g., Kato, 2015). The focus here on ESMs and equality is framed more narrowly. Second, since the focus here is on democratic equality and not human rights or civil liberties per se, I will be mainly concerned with the rights of full citizens of a liberal-democratic state. But this is not to say that much of what follows cannot be extended to non-citizen residents as well.

2 In addition to Habermas's formulation, similar ideas have become widespread among contemporary democratic theorists. See Rawls, 2005; Christiano, 2008; Pettit, 2012; Forst, 2012, 2016.

3 I thank an anonymous reviewer for raising this point.

4 For more general assessments of Gross's model, see, e.g., Cole, 2003; Ackerman, 2006, 88-89; Scheuerman, 2006; 2016; Feldman, 2008.

5 Indeed, precisely this was a byproduct of New York City's 'zone defense' strategy after 9/11, which involved detailed mapping and infiltration of Muslim communities (Goldman and Apuzzo, 2013). A report compiled by Diala Shamas and Nermeen Arastu catalogues instances of persons fearing to attend mosque, distrust of neighbors and newcomers (for fear of informants), cessation of showing news programs in restaurants and cafés (to discourage 'political talk' that could attract attention), and - crucially - fear of speaking out about the surveillance itself (Shamas and Arastu, 2013). 


\section{References}

Ackerman, B. (2006) Before the Next Attack: Preserving Civil Liberties in an Age of Terrorism. New Haven: Yale University Press.

Agamben, G. (2005) State of Exception, trans. K. Attell. Chicago: Chicago University Press.

Amnesty International. (2016) Upturned Lives: The Disproportionate Impact of France's State of Emergency, 3 February (EUR 12/3364/2016).

Amnesty International. (2017) Dangerously Disproportionate: The Ever-Expanding National Security State in Europe, 17 January (EUR 01/5342/2017).

Anderson, E. (1999) What is the point of equality? Ethics 109(2): 287-337.

Armstrong, C. (2006) Rethinking Equality: The Challenge of Equal Citizenship. Manchester, UK: Manchester University Press.

Atkin, L. (1941) Liversidge $v$ Anderson, UKHL 1.

Awan, I. (2012) 'I am a Muslim not an extremist': How the prevent strategy has constructed a 'suspect' community. Politics \& Policy 40(6): 1158-1185.

Banks, R.R. (2003) Beyond profiling: Race, policing, and the drug war. Stanford Law Review 56(3): 571-603.

Bobbio, N. (1990) Liberalism and Democracy. London: Verso.

Capers, B. (2011) Rethinking the fourth amendment: Race, citizenship, and the equality principle. Harvard Civil Rights-Civil Liberties Law Review 46(1): 1-49.

Chesterman, S. (2012) Deny everything: Intelligence activities and the rule of law. In V.V. Ramraj (ed.) Emergencies and the Limits of Legality. Cambridge, UK: Cambridge University Press, pp. 314-333.

Chin, G. (2013) Race and the disappointing right to counsel. Yale Law Journal 122(8): 2236-2259.

Christiano, T. (2008) The Constitution of Equality: Democratic Authority and its Limits. Oxford: Oxford University Press.

Cohen, J.L. (1996) Democracy, difference, and the right to privacy. In S. Benhabib (ed.) Democracy and Difference: Contesting the Boundaries of the Political. Princeton: Princeton University Press, pp. 187-217.

Cole, D. (1999) No Equal Justice: Race and Class in the American Justice System. New York: The New Press.

Cole, D. (2003) Judging the next emergency: Judicial review and individual rights in times of crisis. Michigan Law Review 101(8): 2565-2595.

Crenshaw, K.W. (2019) Unmasking colorblindness in the law: Lessons from the formation of critical race theory. In K.W. Crenshaw, L.C. Harris, D.M. HoSang and G. Lipsitz (eds.) Seeing Race Again: Countering Colorblindness Across the Disciplines. Oakland: University of California Press, pp. 52-84.

Dansky, K., et al. (2014) War Comes Home: The Excessive Militarization of American Policing. New York: American Civil Liberties Union.

Dyzenhaus, D. (2012) The compulsion of legality. In V.V. Ramraj (ed.) Emergencies and the Limits of Legality. Cambridge, UK: Cambridge University Press, pp. 33-59.

Feldman, L. (2008) Judging necessity: Democracy and extra-legalism. Political Theory 36(4): 550-577.

Forst, R. (2012) The Right to Justification: Elements of a Constructivist Theory of Justice, trans. J. Flynn. New York: Columbia University Press.

Forst, R. (2016) The justification of basic rights: A discourse-theoretical approach. Netherlands Journal of Legal Philosophy 45(1): 7-28.

Fourie, C., Schuppert, F. and Wallimann-Helmer (eds.) (2015) Social Equality: On What It Means to Be Equals. Oxford: Oxford University Press. 
Garrau, M. and Laborde, C. (2015) Relational equality, non-domination, and vulnerability. In C. Fourie, F. Schuppert and I. Wallimann-Helmer (eds.) Social Equality: On What It Means to Be Equals. Oxford: Oxford University Press, pp. 45-64.

Goldman, A. and Apuzzo, M. (2013) Enemies Within: Inside the NYPD's Secret Spying Unit and Bin Laden's Final Plot Against America. New York: Simon \& Schuster.

Gotanda, N. (1991) A critique of 'our constitution is color-blind'. Stanford Law Review 44(1): 1-68.

Gross, O. (2003) Chaos and rules: Should responses to violent crises always be constitutional? Yale Law Review 112(5): 1011-1134.

Gross, O. and Ní Aoláin, F. (2006) Law in Times of Crisis: Emergency Powers in Theory and Practice. Cambridge, UK: Cambridge University Press.

Habermas, J. (1996) Between Facts and Norms: Contributions to a Discourse Theory of Law and Democracy, trans. W. Rehg. Cambridge, MA: MIT Press.

Hall, A. and Coyne, C. (2013) The militarization of U.S. domestic policing. Independent Review 17(4): 485-504.

Hayward, C. R. (2011) What Can Political Freedom Mean in a Multicultural Democracy? Political Theory 39(4): 468-497.

Hussain, N. (2007) Beyond norm and exception: Guantánamo. Critical Inquiry 33(4): 734-53.

Hillyard, P. (1993) Suspect Community: People's Experience of the Prevention of Terrorism Acts in Britain. London: Pluto Press.

Human Rights Watch, (2016) France: Abuses Under State of Emergency, 3 February. https://www.hrw. org/print/286497.

Ingram, J.D. (2013) Radical Cosmopolitics: The Ethics and Politics of Universalism. New York: Columbia University Press.

Kasravi, N. et al. (2014) Born Suspect: Stop-and-Frisk Abuses \& the Continued Fight to End Racial Profiling in America, 1st ed. Baltimore: National Association for the Advancement of Colored People.

Kato, D. (2015) The tragic legality of racial violence: Reconstruction, race, and emergency. Constellations 22(2): 199-217.

Klarman, M.J. (2000) The racial origins of modern criminal procedure. Michigan Law Review 99(1): 48-97.

Kraska, P.B. and Kappeler, V.E. (1997) Militarizing American police: The rise and normalization of paramilitary units. Social Problems 44(1): 1-18.

Kraska, P.B. (2007) Militarization and policing - Its relevance to $21^{\text {st }}$ century police. Policing 1(4): 501-513.

Lazar, N.C. (2009) States of Emergency in Liberal Democracies. New York: Cambridge University Press.

Lever, A. (2006) Privacy rights and democracy: A contradiction in terms? Contemporary Political Theory 5(2): 142-162.

Lock, E.D., Timberlake, J.M. and Rasinski K.A. (2002) Battle fatigue: Is public support waning for 'war'-centered drug control strategies? Crime \& Delinquency 48(3): 380-398.

Locke, J. (1980 [1690]) Second Treatise of Government, ed. C.B. Macpherson. Indianapolis: Hackett.

MacKinnon, C.A. (2011) Substantive equality: A perspective. Minnesota Law Review 96(1): 1-27.

Marshall, T.H. and Bottomore, T. (1992) Citizenship and Social Class. London: Pluto Press.

Mehozay, Y. (2016) Between the Rule of Law and States of Emergency: The Fluid Jurisprudence of the Israeli Regime. Albany: SUNY Press.

Moeckli, D. (2008) Human Rights and Non-Discrimination in the 'War on Terror'. Oxford: Oxford University Press.

Neuborne, B. (2011) The gravitational pull of race on the warren court. Supreme Court Review 2010(1): 59-102. 
Nielsen, A.L. (2010) Americans' attitudes toward drug-related issues from 1975-2006: The roles of period and cohort effects. Journal of Drug Issues 40(2): 461-494.

Pantazis, C. and Simon, P. (2009) From the 'old' to the 'new' suspect community. British Journal of Criminology 49(5): 646-666.

Pettit, P. (2012) On the People's Terms: A Republican Theory and Model of Democracy. Cambridge, UK: Cambridge University Press.

Posner, E. and Vermeule, A. (2011) The Executive Unbound: After the Madisonian Republic. Oxford: Oxford University Press.

Ramraj, V.V. (ed.) (2012) Emergencies and the Limits of Legality. Cambridge, UK: Cambridge University Press.

Rawls, J. (2005) Political Liberalism. New York: Columbia University Press.

Reeves, J.L. and Campbell, R. (1994) Cracked Coverage: Television News, The Anti-Cocaine Crusade, and the Reagan Legacy. Durham, NC: Duke University Press.

Rossiter, C.L. (2002 [1948]) Constitutional Dictatorship: Crisis Government in Modern Democracies. New Brunswick: Transaction Publishers.

Scheffler, S. (2003) What is egalitarianism? Philosophy \& Public Affairs 31(1): 5-39.

Scheuerman, W.E. (2006) Emergency powers and the rule of law after 9/11. Journal of Political Philosophy 14(1): 61-84.

Scheuerman, W.E. (2016) Crises and extralegality from above and below. In P. Kjaer and N. Olsen (eds.) Critical Theories of Crisis in Europe: From Weimar to the Euro. London: Rowman \& Littlefield International, pp. 197-212.

Schmitt, C. (1985 [1922, 1934]) Political Theology: Four Chapters on the Concept of Sovereignty, trans. G. Schwab. Cambridge, MA: MIT Press.

Shamas. D. and Arastu, N. (2013) Mapping Muslims: NYPD Spying and Its Impact on American Muslims, joint report by the Muslim American Civil Liberties Coalition (MACLC), the Creating Law Enforcement Accountability \& Responsibility (CLEAR) project, and the Asian American Legal Defense and Education Fund (AALDEF). New York: CLEAR Project, CUNY School of Law.

Sklansky, D.A. (2005) Police and democracy. Michigan Law Review 103(7): 1699-1830.

Sorell, T. (2013) Emergencies and Politics: A Sober Hobbesian Approach. Cambridge, UK: Cambridge University Press.

Stuntz, W.J. (1997) The uneasy relationship between criminal procedure and criminal justice. The Yale Law Journal 107(1): 1-76.

Stuntz, W.J. (2008) Unequal justice. Harvard Law Review 121(8): 1969-2040.

Tushnet, M. (2012) The political constitution of emergency powers: Some conceptual issues. In V.V. Ramraj (ed.) Emergencies and the Limits of Legality. Cambridge, UK: Cambridge University Press, pp. 145-155.

Viehoff, D. (2014) Democratic equality and political authority. Philosophy \& Public Affairs 42(4): $337-375$.

Waldron, J. (2003) Security and liberty: The image of balance. Journal of Political Philosophy 11(2): $191-210$.

Williams, B. (2005) In the Beginning was the Deed. Princeton: Princeton University Press.

Publisher's Note Springer Nature remains neutral with regard to jurisdictional claims in published maps and institutional affiliations. 